\title{
THE INFLUENCE OF POLITICAL AND SOCIAL GLOBALISATION ON FOREIGN DIRECT INVESTMENT INFLOW IN DEVELOPING COUNTRIES: THE ROLE OF FINANCIAL DEVELOPMENT AS A MODERATING FACTOR
}

\author{
Marhamah Mohd Rafidi ${ }^{1}$, Jamaliah Said ${ }^{1 *}$, Naila Erum ${ }^{2}$ and \\ Farha Abdol Ghapar ${ }^{3}$ \\ ${ }^{1}$ Accounting Research Institute (HICoE), \\ Universiti Teknologi MARA, Malaysia. \\ ${ }^{2}$ National Defence University, Islamabad, Pakistan. \\ ${ }^{3}$ Kolej Universiti Poly-Tech MARA, Cheras, Kuala Lumpur, Malaysia.
}

\begin{abstract}
This study presents the effect of political and social globalisation on Foreign Direct Investment (FDI) inflow in developing countries. The eminence of decomposed globalisation element in the FDI area is argued here. New insights into empirical evidence are offered by dropping economic globalisation as one of the decomposed components. A panel data of 42 developing countries from 1984 until 2016 was used by applying the CSARDL approach. The study is also on the impact of political and social globalisation in developing countries by splitting them into two income stratification: Upper Middle-income Countries and Lower Middle-Income Countries by incorporating financial development as a moderating variable. It documents that political globalisation postulates a U-shaped relationship after addressing the Cross-Sectional Dependence (CD) problem, while social globalisation reverses the U-shaped relationship. It was found that political globalisation and social globalisation are conditional to the level of income rather than the overall developing countries' stream. Besides, the prominent role of financial development in promoting FDI inflow, especially to income level, was observed. We suggest that developing countries should increase the capacity to absorb political and social globalisation in promoting FDI.
\end{abstract}

Keywords: FDI inflow, globalisation, political globalisation, social globalisation, financial development, CS-ARDL

ARTICLE INFO

Article History:

Received: 15 February 2021

Accepted: 19 March 2021

Published: 30 April 2021

* Corresponding Author: Jamaliah Said. E-mail: jamaliah533@uitm.edu.my 


\section{INTRODUCTION}

In the imperfection market hypothesis, the impact of FDI inflow forces the domestic business to sustain by merging with foreign multinational companies, resulting in reshaping the country's economic development to be resilient to an economic shock. However, during this globalisation era, FDI inflow activities are encouraged. Through globalisation, economies, politics, social and financial are connected and integrated, thus easing the process of capital movement and leads to a high FDI inflow trend. Our stance of examining the impact of globalisation on foreign direct investment incorporating the decomposed measures of globalisation and financial development is motivated by several opinions.

First, previous studies showed mixed findings. There is literature that declares the positive effect of globalisation toward FDI inflow through encouraging the mobilisation of non-local workers, macroeconomic stability, trade liberalisation, and many more. The adoption of globalisation leads to massive activities of the international capital market that are beneficial to FDI inflow in developing countries (Hammudeh et al., 2020). Since the 1990s, the transitional economies of Europe have had earned more economic gains from other developing countries via financial integration and trade liberalisations. Nevertheless, it was also argued that globalisation's impact depends on the flexibility and readiness of the economy to take over the opportunity and benefit from the enforcement of globalisation (Howell, 2001). Several past studies highlight that globalisation is profound after the threshold level due to symmetric information in the financial markets, institutional quality, and a desirable composition of capital inflows in capital importing countries (Arestis et al., 2005; Stiglitz, 2000; Wei, 2006). However, we highlight the insufficiency of empirical evidence confirming the proposition. Our work adopts Hammudeh et al. (2020) study, where they replicate past studies and proved that globalisation is eminent to growth by considering the nuances element. Hence, we are motivated to view the impact of globalisation on foreign direct investment.

Second, globalisation depends on the absorbing capacity of the country's economy (Darusalam et al., 2019; Hammudeh et al., 2020). Countries such as Latin America, India, China, Hong Kong experience income inequality due to massive trade internalisation in the 1980s and 
1990s (Wei \& Wu, 2002; Wood \& Ridao-Cano, 1999). Southeast Asia adapted massive international trade, including FDI inflow and colossal trade policy reform after removing trade barriers during 1960s and 1970s (Wood \& Ridao-Cano, 1999). The study focuses on global financial crises and growth (Aryeetey \& Ackah, 2011; Milanovic, 2003). Hammudeh et al. (2020) highlight that globalisation and growth depend on income classification. But they have not examined the globalisation-FDI inflow nexus. We resolve the continuing debate by pointing out that FDI inflow and globalisation also depend on income classification.

Third, past studies claim that the effect of globalisation on FDI inflow is provisional interaction of financial development. Globalisation generates new market prospects for many countries. Financial Development plays an important moderating role to the market opportunities, lumpy capital investment in the globalisation, and FDI inflow. Financial markets' development can encompass the globalisation benefits via the channel of FDI by investment decisions, raising savings and augmenting the transfer of capital to its effective uses (Hammudeh et al., 2020; Hermes \& Lensink, 2003; King \& Levine, 1993; Kose et al., 2009; Demirguc-Kunt \& Levine, 1996; Batten \& Vo, 2009; Levine, 2005). Despite the profound role of Financial Development in the globalisation and FDI inflow nexus, the literature has not contextualised the role of financial development as an interaction term in the FDI inflow area. Hence, we are interested in fulfilling the previous literature's loophole by considering the possible element, including financial development, while scrutinising the decomposed component of globalisation-FDI inflow nexus.

The study contributes to the existing literature in several ways. First, we cover a sample of developing countries, and we divided them according to their income level to ensure the comprehensiveness of our analysis. Second, we capture the time-varying dimension of globalisation in driving FDI inflow by using a dynamic approach. Third, we deploy the most appropriate econometric, which is cross-sectionally augmented autoregressive distributed lag (CS-ARDL) approach. This method effectively captures cross-sectional dependency, potential simultaneity, spatial spillover and omitted common factor bias among a large sample of middle-income countries and 33 years of time series methodology. Fourth, we include two out of three decomposed globalisation components and 
financial development as additional factors of FDI inflow which is unique to the body of literature.

The paper is structured as follows: part two presents the literature review. Part three is about methodology. Part four discusses the results and findings. Part five consists of the conclusion and policy implications.

\section{LITERATURE REVIEW AND HYPOTHESES DEVELOPMENT}

\section{Political and Social Globalisation - FDI Inflow}

Political globalisation refers to the growing power of global institutional governance such as the World Bank, International Monetary Fund (IMF), and the World Trade Organisation (WTO) (Crouch, 2012). According to Martell (2007), political globalisation stimulates capital movement, international trade, high technology, transportation, and socioeconomic conditions. The presence of globalisation promotes global country growth (Hammudeh et al., 2020) and FDI (Dreher, 2006). To be specific, past studies argue that the impact of political globalisation is counterproductive to economic growth as it leads to poor governance, poor democracy, political instability, geopolitical uncertainty, and colonial background (Hammudeh et al., 2020; Acemoglu \& Robinson, 2000). The country with poor governance induces a lack of policy credibility, external and internal conflict, and high corruption leading to an inability to open market approach and unable to enjoy political globalisation benefits. The amalgamation of politics will establish a friendly market approach with the United Nations (UN) agencies' assistance, diplomatic relations, and membership in international treaties, creating vast market opportunity, bargaining power of developing countries, and huge capital movement or FDI inflow. Political globalisation aims to create a friendly market and reduce political implications that might harm the FDI inflow movement through diplomatic relationships. In contrast, Dorgan and Arslan found political globalisation and social globalisation have nothing to do with FDI inflow. However, we question the empirical evidence as we review the scarcity on the estimation.

$\mathbf{H}_{1}$ : Political Globalisation influence FDI inflow based on the level of income. 
Social globalisation refers to the transmission of ideas, meaning, and values worldwide in such a way as an extended social relation (Aditya, 2006). A past study argues that social globalisation is counterproductive over economic growth, including the performance of FDI inflow at the beginning of globalisation attack. The negative trend is due to different cultures, such as religious and ethical barriers that lead to conflict for the recipient countries. Developing countries often experienced drawbacks of social globalisation due to poor ability to absorb social globalisation impact. Competitive pressures from trade liberalisation violate social welfare standards, environmental standards, and worker protection legislation and are detrimental to the capital movement (Hammudeh et al., 2020). The penetration of social liberal ideas or social globalisation impact would minimise income inequality by improving the internal Human Rights Act (Rosenau, 2003). Allowing social globalisation will establish government awareness to enhance the policy that protects civil society from actions by states and agents. Globalisation immerses the protection of human rights, cultural, civil, and political aspects (Arfat, 2013). Globalisation allows technology spillover (Hammudeh et al., 2020); thus, it creates an easy gateway for social globalisation to lay beneath the society and government. This creates ease for FDI to mobilise.

$\mathbf{H}_{2}$ : Social Globalisation influence FDI inflow based on the level of income.

\section{Political and Social Globalisation and FDI inflow: The Role of Financial Development}

The literature has argued that the role of financial development is profound in many areas such as environmental Kuznets (Katircioglu \& Taspinar, 2017 and Rahman and Chen et al., 2019) globalisation (Hammudeh et al., 2020) but limited in the FDI area. In addition, rampant financial development and financial institutions influence mobilisation capital or FDI and trade liberalisation (Mauro, 1995; Olson et al., 2000; North, 1990; Rosenberg \& Birdzell, 1985; King \& Levine, 1993a; Rajan \& Zingales, 1998). Financial development aims to catalyst effective investment cost and invite more greenfield and brownfield FDI (Mishkin, 2009). Strong financial development should enhance governance and FDI inflow (Levine, 2005; Alfaro et al., 2009; Rad et al., 2016). In conjunction with that, financial liberalisation and financial development can effectively maximise capital 
(Hermes \& Lensink, 2003; Carkovic \& Levine, 2005; Kose et al., 2009; King \& Levine, 1993b; Beck et al., 1999; Demirguc-Kunt \& Levine, 1996; Levine, 2005; Federici \& Carioli, 2009; Kose et al., 2010; Ang, 2008). The globalisation process positively influences domestic economic growth by developing the financial markets and institutions, financial integration, capital accumulation, and trade liberalisation (Mauro, 1995; Olson et al., 2000; North, 1990; Rosenberg \& Birdzell, 1985; King \& Levine, 1993a; Rajan \& Zingales, 1998). Additionally, the international level of financial development can effectively maximise capital (Hermes \& Lensink, 2003; Carkovic \& Levine, 2005; Kose et al., 2009; Beck et al., 1999; DemirgucKunt \& Levine, 1996; Levine, 2005; Federici \& Carioli, 2009; Kose et al., 2010; Ang, 2008). Vast and strong financial development should enhance governance and FDI inflow (Levine 2005; Alfaro et al., 2009; Rad et al., 2016). Another literature review argued that financial development is a significant factor welcoming globalisation such as Mauro (1995), Olson et al. (2000), North (1990), Rosenberg and Birdzell (1985), King and Levine (1993a), Rajan and Zingales (1998). An agency tends to embrace incentives to improve corporate governance through external financial sources to reduce agency problems due to globalisation (Stulz, 2005). We argue that globalisation is sensitive to FDI inflow by the support of financial development. We estimate globalisation nexus into two-component systems, which are political globalisation and social globalisation.

$\mathbf{H}_{3}$ : The impact of political and social globalisation on FDI inflow is sensitive to the Financial Development.

\section{METHODOLOGY}

\section{Data and Source}

We deploy our model and proposition based on the income level proposed by the World Bank Group. We adopt the approach of Hammudeh et al. (2020). From 139 of the total population listed in the World Bank Group, only 42 selected countries remain as the sample of the study. From 40 countries, 19 were recognised as upper Middle-Income countries, and 23 recognised as lower-middle-income countries. This study considers data from the year of 1984 until 2016. Most of the data were transformed 
into natural $\log$. This is due to the different real units of each variable. The dependent variable is FDI inflows, while the independent variable is political globalisation and social globalisation. We incorporate financial development with political and social globalisation as an interaction term because we believe financial development will encourage FDI inflow together with political and social globalisation. We gather political and social globalisation in the KOF globalisation database. FDI inflows, labour force inflation rate, and carbon emission were collected from the World Development Indicators (WDIs) from the World Bank database.

\section{Cross-Sectional Dependence (CD) and Second-Generation Panel Unit Root}

This study applied the cross-sectional dependence (CD) test developed by Pesaran (2004). We assume that our sample countries are integrated through investment and trade activities, leading to the spillover effect. Second generation unit root analysis was developed to overcome crosssectional dependency issues (Bai \& Ng, 2004; Moon \& Perron, 2004; Pesaran, 2007). Cross-sectional dependency is a major issue in panel data especially study related to social sciences (Im et al., 2003; Sarafidis \& Wansbeek, 2010) as many factors are interrelated and non-independent, for example, person, groups, and social characteristics (Stephan, 1934, pg. 165). CD contemporaneously perhaps due to counts, selecting individuals non-randomly, unobserved common shocks, due to a single currency, the common agro-climatic environment; and policies adopted by the central authority (Basak \& Das, 2018). Failure to compliment CD shall immensely distort modelling (O'Connell, 1998). The null hypothesis of CD shows no cross-sectional dependence among the sample of countries. The alternative hypothesis proposed CD exists among sample countries. The equation of the $\mathrm{CD}$ test is as follow:

$C D=\left(\frac{T N(N-1}{2}\right)^{1 / 2} \underline{\hat{P}}$

where

$$
\underline{\hat{\rho}}=\left(\frac{2}{N(N-1)}\right) \sum_{i=1}^{N-1} \quad \sum_{j=i+1}^{N} \quad \hat{\rho}_{i j} \cdot \hat{\rho}_{i j}
$$


$\hat{\rho}_{i j}$ indicates pair-wise correlation coefficient for cross-sectional residuals provided by Augmented Dickey-Fuller (ADF) regression. $N$ and $T$ designate cross-section and time dimensions. After this, we applied CrossSectional Augmented Dickey-Fuller (CADF) unit root test. It indicates the cross-sectional correlation coefficient of the residual obtained from regression. Hence, this study applies the CD test developed by Pesaran (2004) to investigate coexistent correlation across countries.

Next, we applied the cross-sectional augmented Dickey-Fuller (CADFI unit root test.

$$
\Delta Y_{i t}=\alpha_{i}+\beta_{i} Y_{i t-1}+\gamma_{i} \underline{Y}_{t-1}+\phi_{i} \Delta \underline{Y}_{t}+\varepsilon_{i t}
$$

Here, $i=1, \ldots . N, t=1, \ldots ., T$ and $\underline{Y}_{t}$ are cross-sections mean and is generated from $\underline{Y}_{t}=N^{-1} \sum_{i}^{N} \quad N i=1 Y_{i t}$. The consideration of mean alleviates the presence of correlation among $Y_{i t}$.

The null hypothesis for $\mathrm{Eq} \# 1$ is $H_{0}: \beta_{i}=0$ for all $i$ and the alternate hypothesis is $H_{1}: \beta_{i}<0$ for some $i$.

Meanwhile, the equation of cross-sectionally augmented Im-PesaranShin (CIPS) panel unit root test is as follow:

$$
\operatorname{CIPS}(N, T)=N^{-1} \sum_{i=1}^{N} 1 t_{i}(N, T)
$$

Or

$$
N^{-1} \sum_{i=1}^{N} t *_{i}(N, T) \text { where } t_{i}(N, T) \text { indicates the t-statistic of. }
$$

Where, $t_{i}(N, T)$ indicates the t-statistics for $\beta_{i \text {. }}$

\section{Cross-Sectional-Autoregressive Distributed Lag (CS-ARDL) Test}

The variable included in the study theoretically has the strong potential to be cross-sectionally dependent. Due to developing countries, they are integrated through the blockchain of investment, the spillover of technology, 
information and communication, globalisation, etc. Thus, we applied the Cross-Sectional Autoregressive Distributed Lag (CS-ARDL). CS-ARDL developed by Chudik et al. (2016) aimed to tackle the presence of common unobserved effects effectively. CS-ARDL allows this study to include lagged on dependent variables, allow weakly exogenous regressors, and develop an error correction framework (ECM) to capture dynamic behaviour.

This approach is also consistent in the presence of endogenous and serial correlation. In this study, the dependent variable, which is FDI inflow and independent variables (i.e., political globalisation, and social globalisation) other control variables (i.e., carbon emission, inflation rate, and labour force) tend to have a serious cross-sectional problem. This is because host countries that bound under emerging countries were integrated with political, economic, and social integration as well as technological and spatial spillover, financial development, trade, and others (Pesaran \& Tosetti, 2011).

This approach is also capable of addressing cross-sectional dependence in both short-run and long-run relationships. The applied estimator of the mean group (MG) is based on CS-ARDL assumptions and is asymptotically unbiased as for both fixed. We estimate the potential cross-sectional bias in three different versions, which are short-run, long-run, and in both shortrun and long run. Hence, the CS-ARDL equations for baseline regression are as follow:

$$
\begin{aligned}
& \Delta l f d i c_{i t}=\mu_{i}+\varphi_{i}\left(\text { lfdic }_{i t-1}-\beta_{i} X_{i t-1}-\phi_{1 i} \text { lfdic }_{t-1}-\phi_{2 i} \underline{X_{t-1}}\right)+ \\
& \sum_{j=1}^{p-1} \lambda_{i j} \Delta l f d i c_{i t-j}+\sum_{j=0}^{q-1} \zeta_{i j} \Delta X_{i t-j}+\eta_{1 i} \Delta \underline{\underline{\operatorname{lfic_{t}}}+\eta_{2 i} \Delta \underline{X}_{t}+\varepsilon_{i t}}
\end{aligned}
$$

Where $\triangle L F D I_{i t}$ is the dependent variable whereas $X_{i t-1}$ represent all

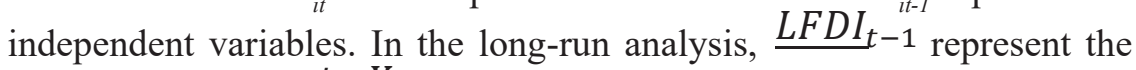
dependent variable, $\phi_{2 i} \underline{X}_{t-1}$ represent all independent variables during the long run. The equation also considers the short run, therefore, $\eta_{1 i} \Delta L F D I_{t}$ depicted dependent variable for short-run and $\eta_{2 i} \Delta \underline{X}_{t}$ portray independent variables during the short run. 


\section{The Framework of The Model}

We adapted the study of Hammudeh et al. (2020). We further extend our model as highlighted in equation (M1) and (M1)

$$
\begin{aligned}
& \text { lfdic }_{i t}=\alpha_{0}+\beta_{1} P G I_{i t}+\beta_{2} S G I_{i t}+\beta_{3} P G I^{*} F D_{i t}+\beta_{4} S G I^{*} F D_{i t}+\beta_{4} C O 2 \\
& +\beta_{3} I N F_{i t}+\beta_{4} L B F_{i t}+\varepsilon_{i t}, \\
& \text { (fdic } c_{i t}=\alpha_{0}+\beta_{1} P G I_{i t}+\beta_{2} S G I_{i t}+\beta_{3} P G I^{*} F D_{i t}+\beta_{4} S G I^{*} F D_{i t}+\beta_{4} C O 2 \\
& +\beta_{3} I N F_{i t}+\beta_{4} L B F_{i t}+\varepsilon_{i t}, \text { if } d c i=1 \text { or } d c i=0
\end{aligned}
$$

Where,

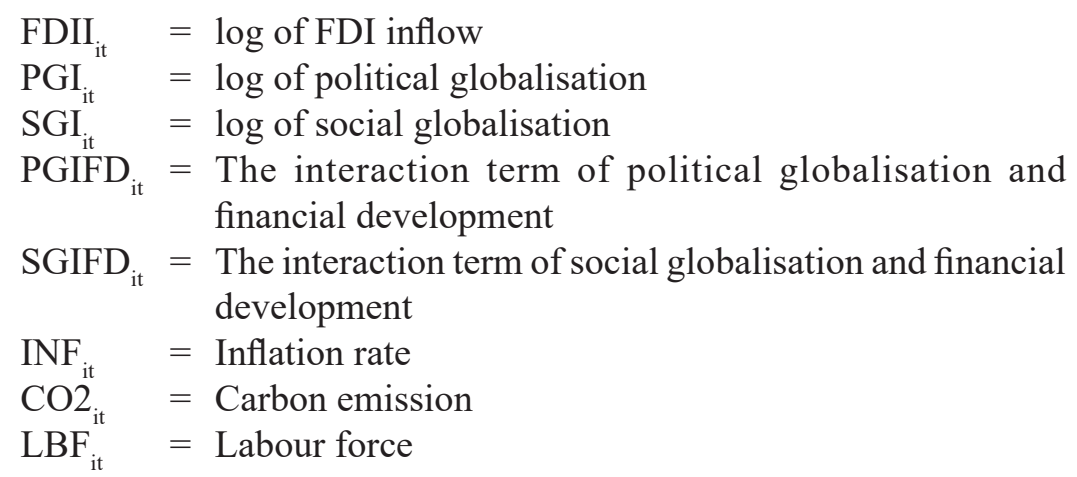

The model of this study focuses on the impact of the quality of governance before and after the threshold point towards Foreign Direct Investment Inflows as well as the conditional presence of Financial development. We control the model with the inflation rate and carbon emission, and the labour force. We consider income stratification level; thus, $\mathrm{dci}=1$ and $\mathrm{dci}=0$ represent the stratification level. 


\section{FINDINGS AND DISCUSSION}

\section{Descriptive Analysis}

Table 1: Descriptive Analysis

\begin{tabular}{lccccccc}
\hline \multicolumn{1}{c}{ Variables } & \multicolumn{1}{c}{$\mathbf{N}$} & \multicolumn{1}{c}{ Mean } & \multicolumn{1}{c}{$\mathbf{5}$} & \multicolumn{1}{c}{ Median } & $\mathbf{9 5 \%}$ & SD & \multicolumn{1}{c}{ Skew } \\
\hline LFDIC & 1,386 & 20.06921 & 16.02326 & 20.28552 & 23.70789 & 2.364142 & -.491467 \\
LAFD & 1,386 & 3.839897 & 3.206631 & 3.913871 & 4.258503 & .3470035 & -1.613341 \\
LPGI & 1,386 & 4.140492 & 3.514522 & 4.221172 & 4.495148 & .3070908 & -.9127315 \\
LSGI & 1,386 & 3.42843 & 2.334314 & 3.546832 & 4.105403 & .529348 & -1.212334 \\
$\mathrm{CO}_{2}$ & 1386 & 2.366838 & .5901188 & 2.345894 & 3.535036 & 1.719386 & 3.739229 \\
INGFDP & 1,386 & 71.52753 & -.7422882 & 7.772474 & 94.31957 & 606.6352 & 16.50262 \\
LBF & 1,386 & 16.04329 & 13.47401 & 16.10441 & 18.61589 & 1.658492 & .2813175 \\
\hline
\end{tabular}

Table 1 presents the descriptive statistics of our variables in logarithmic form. The sample statistics show that the mean value and the standard deviation of FDI inflow (FDII) are 20.06 and 2.364, respectively. The mean values of political globalisation $(P G I)$ and Social globalisation (SGI), Carbon emission (CO2), inflation rate (INF) and labour force (LBF) are $3.514,2.334,1.563,2.366,71.52$, and 16.043 accordingly, suggesting the carbon emission is smaller than other domain variables.

\section{CD and Order Cointegration}

Table 2: CD Analysis and Second-Generation Unit Root Analysis

\begin{tabular}{|c|c|c|c|c|c|c|c|}
\hline Variable & CD & $\begin{array}{l}\text { Abs } \\
\text { (corr) }\end{array}$ & $\begin{array}{l}\text { CIPS } \\
\text { (level) }\end{array}$ & $\begin{array}{c}\text { CIPS } \\
\text { (1 }{ }^{\text {st }} \text { diff) }\end{array}$ & $\begin{array}{c}\text { CIPS } \\
\left(2^{\text {nd }} \text { Diff) }\right.\end{array}$ & $\begin{array}{c}\text { CIPS } \\
\text { (Level \& } \\
\text { Trend) }\end{array}$ & $\begin{array}{c}\text { CIPS } \\
\text { (Trend \& } \\
1^{\text {st }} \text { diff) }\end{array}$ \\
\hline LFDII & $119.66^{* * *}$ & 0.710 & $-6.239^{* * *}$ & $-21.923^{* * *}$ & $-29.196^{* * *}$ & $-3.137^{* * *}$ & $-19.471^{* * *}$ \\
\hline LAFD & $131.15^{\star * *}$ & 0.853 & $-5.382^{* * *}$ & $-15.533^{* * *}$ & $-27.341^{* * *}$ & $-2.339^{* * *}$ & $-14.334^{* * *}$ \\
\hline LPGI & $108.65^{\star * *}$ & 0.658 & $-5.728^{* * *}$ & $-16.606^{\star \star \star}$ & $-26.325^{\star * *}$ & $-1.963^{* * *}$ & $-15.196^{\star \star *}$ \\
\hline LSGI & $138.40^{* * *}$ & 0.822 & $-5.594^{* * *}$ & $-17.258^{\star * *}$ & $-27.355^{\star * *}$ & 6.500 *** & -15.189 *** \\
\hline $\mathrm{CO}_{2}$ & $6.57^{\star * *}$ & 0.448 & $-3.194^{* * *}$ & $-20.589 * * *$ & $-29.509^{* * *}$ & $-2.899^{\star * *}$ & $-18.813^{\star * *}$ \\
\hline INFGDP & $32.21^{\star * *}$ & 0.258 & $-10.406^{\star \star \star}$ & $-25.940^{* * *}$ & $-29.943^{* * *}$ & $-7.824^{\star \star \star}$ & $-24.015^{\star \star \star}$ \\
\hline LBF & $150.87^{* * *}$ & 0.986 & $-13.908^{a}$ & 2.037 & $-23.377^{* * *}$ & 6.205 & $-7.518^{\star \star *}$ \\
\hline
\end{tabular}

Before analysing our models, we attempt to identify two important characteristics of the variables, including CD and order of integration. First, we apply the CD test by Pesaran, which is crucial to address the problems associated with CD for long panel time-series data (2008) to 
obtain unbiased estimators (Sadorsky, 2013). This test is conducted based on the average pair-wise correlations under the OLS framework. The CD statistics are estimated from the residuals obtained from the individual sample country regressions in the panel. In the second stage, we apply the second-generation (CIPS) panel unit root test that considers the presence of $\mathrm{CD}$. The CIPS test's major objective is to examine the order of integration of the variables to determine the best estimation technique to estimate and analyse our models. A precondition for applying the CS-ARDL approach is the presence of the CD and order of integration that is either I (1) or a mixed order of I (1) and I (0) but not more in the respective variables. We present the $\mathrm{CD}$ test statistics and the average cross-sectional correlations in Table 2. The lowest CD statistic is recorded as 6.57, where the average cross-country correlation is 0.448 for the environmental condition. We observe the existence of $\mathrm{CD}$ and the high average cross-country correlation in all the variables. The results make us notice that developing countries are dependent on each other. We found that all variables in this study are characterised by $\mathrm{CD}$ property, which explains that a macro factor within an economy is linked with the same factor in another economy. This might be happening due to the integration of financial, globalisation, policy, and other factors. Next, we present the results of the panel unit root tests in the same table. We apply the CIPS test suggested by Pesaran (2007). Table 3 shows that all variables appear to be stationary in the level, both with and without a trend. Thus, the presence of $\mathrm{CD}$ and a mixed order of integration endorse the appropriateness of the CS-ARDL approach as the best tool to analyse our models.

\section{Political and Social Globalisation- FDI Inflow}

Table 3: Political and Social Globalisation and FDI Inflow for Developing Countries

\begin{tabular}{|c|c|c|c|c|c|c|}
\hline \multirow[b]{2}{*}{ Variables } & \multicolumn{6}{|c|}{ Developing countries } \\
\hline & $\begin{array}{c}C D \text { in SR } \\
\text { and LR }\end{array}$ & $\begin{array}{c}C D \text { in SR } \\
\text { and LR }\end{array}$ & CD in SR & CD in SR & CD in LR & CD in LR \\
\hline \multirow[t]{2}{*}{ ECM } & & $-0.687^{\star * \star}$ & & $-0.644^{* * *}$ & & $-0.553^{* * *}$ \\
\hline & & $(0.0496)$ & & $(0.0448)$ & & $(0.0433)$ \\
\hline \multirow[t]{2}{*}{$\triangle \mathrm{PGI}$} & & -12.71 & & -8.589 & & 14.38 \\
\hline & & (15.93) & & $(23.76)$ & & $(30.60)$ \\
\hline \multirow[t]{2}{*}{$\Delta \mathrm{PGI}_{2}$} & & 1.468 & & 1.004 & & -1.963 \\
\hline & & $(1.951)$ & & $(2.956)$ & & $(3.782)$ \\
\hline
\end{tabular}




\begin{tabular}{|c|c|c|c|c|c|c|}
\hline \multirow[b]{2}{*}{ Variables } & \multicolumn{6}{|c|}{ Developing countries } \\
\hline & $\begin{array}{c}C D \text { in SR } \\
\text { and } L R\end{array}$ & $\begin{array}{c}C D \text { in SR } \\
\text { and LR }\end{array}$ & CD in SR & CD in SR & CD in LR & CD in LR \\
\hline \multirow[t]{2}{*}{$\Delta S G I$} & & 38.52 & & 51.53 & & 44.93 \\
\hline & & (32.93) & & $(34.27)$ & & (32.61) \\
\hline \multirow[t]{2}{*}{$\Delta \mathrm{SGI}_{2}$} & & -5.188 & & -6.892 & & -6.056 \\
\hline & & $(4.525)$ & & $(4.670)$ & & $(4.450)$ \\
\hline \multirow[t]{2}{*}{$\Delta \mathrm{CO} 2$} & & 0.141 & & 0.0954 & & 0.431 \\
\hline & & $(0.315)$ & & $(0.279)$ & & $(0.301)$ \\
\hline \multirow[t]{2}{*}{$\Delta \mathrm{LBF}$} & & -4.537 & & -3.572 & & -3.315 \\
\hline & & $(4.938)$ & & $(4.937)$ & & $(4.264)$ \\
\hline \multirow[t]{2}{*}{$P G I_{t-1}$} & $-0.506^{*}$ & & 0.513 & & $8.519^{* *}$ & \\
\hline & $(0.267)$ & & $(0.341)$ & & $(4.251)$ & \\
\hline \multirow[t]{2}{*}{$P G I_{2 t-1}$} & $0.0693^{* *}$ & & $0.0670^{*}$ & & $-1.072^{\star *}$ & \\
\hline & $(0.0316)$ & & $(0.0407)$ & & $(0.535)$ & \\
\hline \multirow[t]{2}{*}{$\left.S G\right|_{t-1}$} & $7.914^{* * *}$ & & $1.519^{* * *}$ & & -0.00738 & \\
\hline & $(1.297)$ & & $(0.441)$ & & $(0.715)$ & \\
\hline \multirow{2}{*}{$\mathrm{SGI}_{2 \mathrm{t}-1}$} & $-1.261^{* * *}$ & & -0.00438 & & $0.324^{* *}$ & \\
\hline & $(0.203)$ & & $(0.0662)$ & & $(0.130)$ & \\
\hline \multirow[t]{2}{*}{$\mathrm{CO}_{\mathrm{t}-1}$} & -0.0154 & & $-0.336^{\star * *}$ & & $-0.503^{* * *}$ & \\
\hline & $(0.0915)$ & & $(0.129)$ & & $(0.0912)$ & \\
\hline \multirow{2}{*}{$\mathrm{LBF}_{\mathrm{t}-1}$} & $1.617^{\star * *}$ & & $4.177^{\star \star \star}$ & & $0.673^{*}$ & \\
\hline & $(0.513)$ & & $(0.279)$ & & $(0.360)$ & \\
\hline \multirow[t]{2}{*}{ Constant } & & $-10.06^{\star \star \star}$ & & $-34.85^{\star \star \star}$ & & $-12.76^{\star \star \star}$ \\
\hline & & $(0.764)$ & & $(2.390)$ & & $(1.054)$ \\
\hline $\mathrm{N}$ & 1,343 & 1,343 & 1,343 & 1,343 & 1,343 & 1,343 \\
\hline
\end{tabular}

Note: *** ${ }^{* *},{ }^{*}$ denotes significance at the $1 \%, 5 \%$, and $10 \%$ levels, respectively. We applied the cross-sectionally augmented autoregressive distributive lag (CS-ARDL) methodology proposed by Chudik and Pesaran (2015). We solved the problem of cross-sectional dependence in the short run and long run (M1), short-run (M2), and long-run (M3)

The literature argues that globalisation has a mixed effect on many areas, especially in the FDI field. We propose that the relation between FDI inflow and globalisation follows a non-linear shape. Table 3 reports three models (M1, M2, and M3) that examine the impact of globalisation on FDI inflow in developing countries. We declare that the impact of political globalisation and social globalisation on FDI inflow is conditional in several ways. We address CD both in the short and long run in model M1. Moreover, the $\mathrm{CD}$ is addressed in the short run in model M2 and in the long run in model M3. However, we focus on the results obtained from M1 Table 3. The results from Table 3 suggest that the coefficient of the error correction (EC) is negative and significant under all three models, validating that there is a 
long-run relationship between FDII and PGI and SGI through a short-run economic adjustment process. More precisely, the coefficient implies that the short-run speed of adjustment towards the long-run equilibrium is $60.87 \%$ per year due to economic shock, policy changes, and so on. The penetration of globalisation within politics portrays counterproductive FDI inflow across developing countries. We argue the counter-productivity of FDI inflow at that time is due to the government's insufficient readiness to absorb globalisation's impact. We believe country productivity in the case of FDI inflow is affected by globalisation due to impediment of political structure, but, over time, they may resolve the impediment (Hammudeh et al., 2020). Over time, we found that political globalisation turns to be positive at the threshold point. This is due to flexibility and experience from the past had reshaped the country to welcome globalisation in the political structure. In contrast, we declare that the social structure of developing countries enjoys the advantage of globalisation. The booming of social globalisation leads to overproduction of FDI inflow in developing countries. However, the injection of social globalisation reduces FDI inflow productivity at the threshold point. Social globalisation indeed establishes technology spillover over society. Massive technology spillover might cause society to compromise with corruption and lobbying to tarnish foreign investor trust over the country. Hence, we accept that political globalisation and social globalisation are sensitive to FDI inflow. Our finding has coincided with Stiglitz (2002), who stated that meticulous globalisation does not resolve the economic and social issues among countries.

In this section, we split developing countries into two categories: upper and lower middle-income countries. We intend to view the impact of political and social globalisation on FDI inflow based on income level. The coefficients of the EC for the political and social globalisations in Table 4 are -0.704 , and -0.768 respectively, implying that after any economic shock, the models adjust $70.4 \%$ and $76.8 \%$ per year towards the longrun equilibrium. The coefficients for political globalisation (PGIt-1) are negative and the squared term (PGI2t-1) positive and significant, indicating a possible U-shaped relationship between political globalisation and FDI inflow in upper-middle-income countries. In contrast, political globalisation indicates a reverse $\mathrm{U}$-shape. The coefficient $\left(\mathrm{SGI}_{\mathrm{t}-1}\right)$ initially is positive but insignificant; however, the squared term $\left(\mathrm{PGI}^{2}{ }_{\mathrm{t}-1}\right)$ denotes a positive and significant relationship between political globalisation and FDI inflow 
over time among lower-middle-income countries. We argue that uppermiddle-income countries have received prominence worker remittance, advanced technology spillover, friendly market opportunities due to political globalisation. A growing substantial competitive advantage among upper-middle-income countries had increased the intensity of competition among trading partners. The amalgamation of factors mentioned raises the intensity of the U-shape relationship. We argue that the reverse U-shaped relationship between political globalisation and FDI inflow demonstrated by lower-middle-income countries is due to the insufficient capacity to absorb the vast impact of globalisation, resulting in opposing results (Read, 2004).

Surprisingly, the coefficient of social globalisation indicates a positive relationship and significance while the squared term $\left(\mathrm{SGI}^{2}\right)$ remains positive and significant with the notion that reverse U-shaped relationship among upper-middle-income countries. With that, it denotes social globalisation indicating a U-shaped relationship. The coefficient SGI is negative and significant; however, the squared term depicts positive and significant lowermiddle-income countries. We argue that upper middle-income countries with a better level of income, sufficient governance infrastructure, and resilience absorb the vast impact of globalisation and promote FDI inflow. 


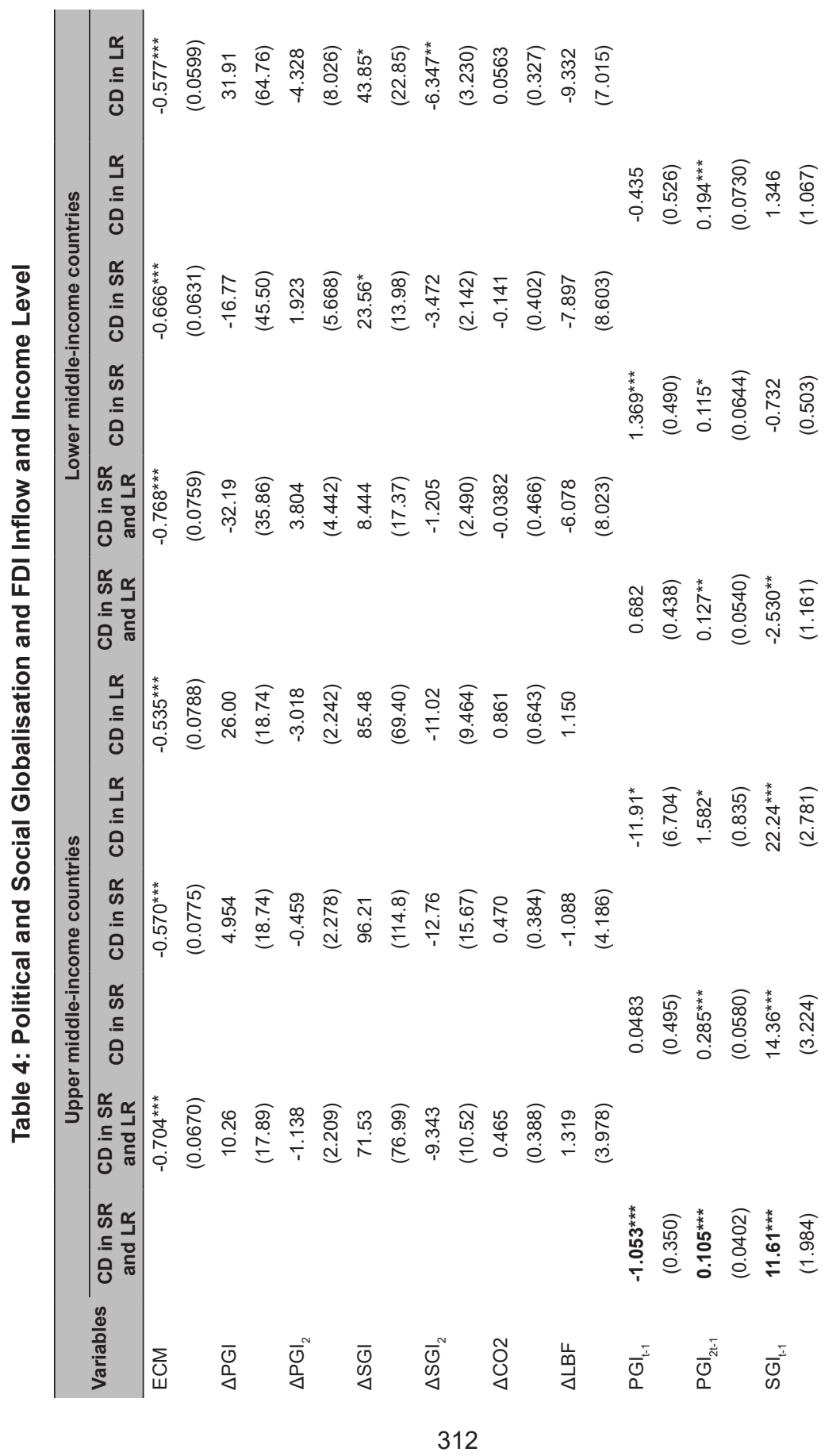




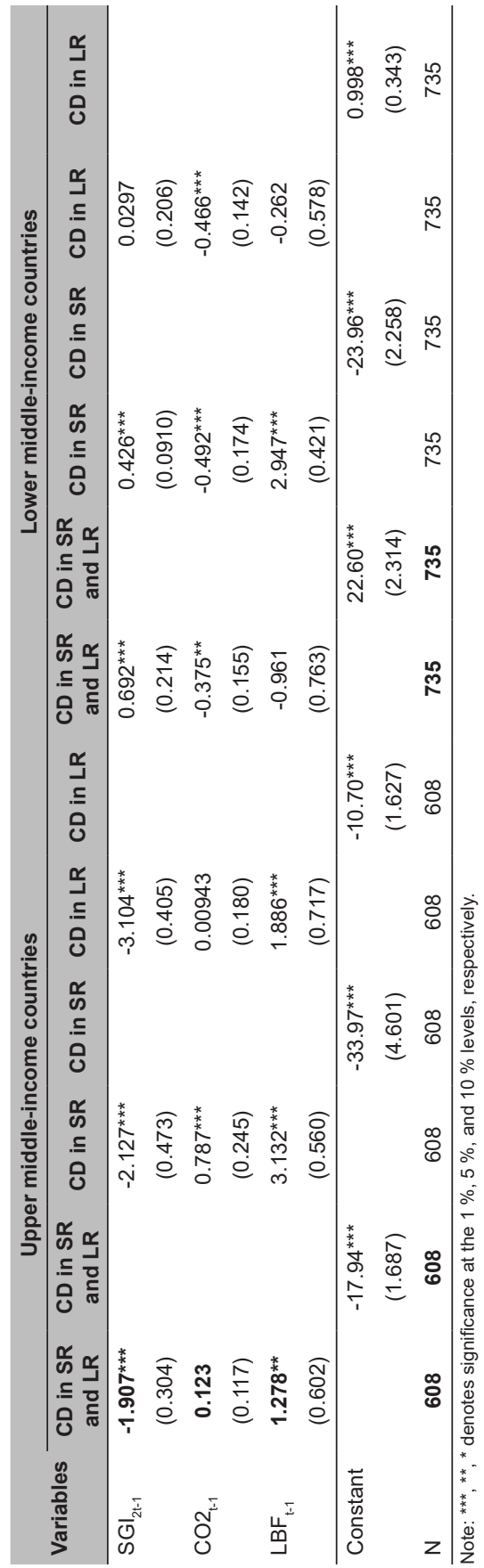


In unison, we believe that social globalisation is negative at starting point due to the impediment of policy, especially to civil and human right laws, but resolve the impediment over time due to the capacity to adopt globalisation; as a result, attract foreign investors (Read, 2004, Hammudeh et al., 2020). Solving political and social impediments will lead to establishing good governance, infrastructure, financial development, socio-economic factors, and so on. In the end, we summarised that political globalisation and social globalisation are sensitive to the level of income and FDI inflow.

\section{Political and Social Globalisation and FDI inflow: The Role of Financial Development}

Table 5: The Impact of Political and Social Globalisation on FDI Inflow: The Role of Financial Development

\begin{tabular}{|c|c|c|c|c|c|c|}
\hline \multirow{2}{*}{ Variables } & \multicolumn{2}{|c|}{ Developing countries } & \multicolumn{2}{|c|}{$\begin{array}{l}\text { Upper middle-income } \\
\text { countries }\end{array}$} & \multicolumn{2}{|c|}{$\begin{array}{l}\text { Lower middle-income } \\
\text { countries }\end{array}$} \\
\hline & $\begin{array}{l}\text { CD in SR } \\
\text { and LR }\end{array}$ & $\begin{array}{l}\text { CD in SR } \\
\text { and LR }\end{array}$ & CD in SR & CD in SR & CD in LR & CD in LR \\
\hline \multirow[t]{2}{*}{ ECM } & & $-0.571^{* * *}$ & & $-0.718^{* * *}$ & & $-0.747^{* * *}$ \\
\hline & & $(0.0458)$ & & $(0.0732)$ & & $(0.0796)$ \\
\hline \multirow[t]{2}{*}{$\triangle \mathrm{PGI}$} & & 20.91 & & -32.38 & & 47.75 \\
\hline & & (35.62) & & (31.61) & & (73.53) \\
\hline \multirow{2}{*}{$\Delta \mathrm{PGI}_{2}$} & & -7.000 & & 6.983 & & -4.733 \\
\hline & & $(8.276)$ & & (12.02) & & (7.648) \\
\hline \multirow[t]{2}{*}{$\Delta \mathrm{SGI}$} & & 41.65 & & 52.10 & & -18.98 \\
\hline & & $(39.80)$ & & $(116.0)$ & & $(43.69)$ \\
\hline \multirow[t]{2}{*}{$\Delta \mathrm{SGI}_{2}$} & & -5.209 & & -9.584 & & 0.483 \\
\hline & & $(9.976)$ & & (20.79) & & (8.694) \\
\hline \multirow[t]{2}{*}{$\triangle \mathrm{PGIFD}$} & & 7.795 & & -5.770 & & -0.448 \\
\hline & & $(18.85)$ & & (28.99) & & $(17.11)$ \\
\hline \multirow[t]{2}{*}{$\triangle$ SGIFD } & & -2.642 & & 5.686 & & 2.658 \\
\hline & & $(21.20)$ & & $(33.68)$ & & (22.94) \\
\hline \multirow[t]{2}{*}{$\Delta \mathrm{CO} 2$} & & 0.395 & & 0.225 & & 0.0545 \\
\hline & & $(0.381)$ & & $(0.354)$ & & $(0.434)$ \\
\hline \multirow[t]{2}{*}{$\Delta \mathrm{LBF}$} & & -8.119 & & 2.898 & & -6.429 \\
\hline & & $(6.333)$ & & $(4.545)$ & & $(8.310)$ \\
\hline \multirow[t]{2}{*}{$\left.P G\right|_{t-1}$} & $12.30^{* * *}$ & & -8.521 & & $2.013^{\star * *}$ & \\
\hline & (3.981) & & $(7.552)$ & & $(0.502)$ & \\
\hline \multirow[t]{2}{*}{$P G I_{2 t-1}$} & $-1.390^{* * *}$ & & 0.919 & & -0.376 & \\
\hline & $(0.500)$ & & $(0.924)$ & & $(0.490)$ & \\
\hline$S G I_{t-1}$ & $1.939^{* *}$ & & $17.43^{\star * *}$ & & $5.006^{\star *}$ & \\
\hline
\end{tabular}




\begin{tabular}{|c|c|c|c|c|c|c|}
\hline \multirow{2}{*}{ Variables } & \multicolumn{2}{|c|}{ Developing countries } & \multicolumn{2}{|c|}{$\begin{array}{c}\text { Upper middle-income } \\
\text { countries }\end{array}$} & \multicolumn{2}{|c|}{$\begin{array}{c}\text { Lower middle-income } \\
\text { countries }\end{array}$} \\
\hline & $\begin{array}{l}\text { CD in SR } \\
\text { and LR }\end{array}$ & $\begin{array}{l}\text { CD in SR } \\
\text { and LR }\end{array}$ & CD in SR & $C D$ in $S R$ & CD in LR & CD in LR \\
\hline & $(0.776)$ & & $(2.830)$ & & $(2.382)$ & \\
\hline \multirow{2}{*}{$\mathrm{SGI}_{2 \mathrm{t}-1}$} & -0.0352 & & $-2.585^{\star \star *}$ & & $3.153^{* \star *}$ & \\
\hline & $(0.130)$ & & $(0.405)$ & & $(0.781)$ & \\
\hline \multirow[t]{2}{*}{ PGIFD $_{t-1}$} & $-0.226^{* * *}$ & & $0.122^{\star *}$ & & $2.371^{* *}$ & \\
\hline & $(0.0664)$ & & $(0.0490)$ & & $(1.047)$ & \\
\hline \multirow[t]{2}{*}{$\mathrm{SGIFD}_{\mathrm{t}-1}$} & 0.00479 & & $-0.177^{* * *}$ & & $-5.580^{\star * *}$ & \\
\hline & $(0.0696)$ & & $(0.0558)$ & & $(1.704)$ & \\
\hline \multirow[t]{2}{*}{$\mathrm{CO}_{\mathrm{t}-1}$} & $-0.481^{* * *}$ & & 0.0892 & & -0.0932 & \\
\hline & $(0.0807)$ & & $(0.141)$ & & $(0.132)$ & \\
\hline \multirow[t]{2}{*}{$\mathrm{LBF}_{\mathrm{t}-1}$} & 0.294 & & $2.426^{\star \star \star}$ & & -0.789 & \\
\hline & $(0.313)$ & & $(0.623)$ & & $(0.873)$ & \\
\hline \multirow[t]{2}{*}{ Constant } & & $-15.18^{* * *}$ & & $-20.25^{\star \star \star}$ & & $12.99^{* \star *}$ \\
\hline & & $(1.310)$ & & $(2.028)$ & & $(1.651)$ \\
\hline $\mathrm{N}$ & 1,343 & 1,343 & 608 & 608 & 735 & 735 \\
\hline
\end{tabular}

This section intends to assess financial development to assist political and social globalisation in promoting FDI inflow. We found that financial development failed to promote FDI inflow when cooperating with political globalisation for all the developing countries. However, we demonstrate the expected result after splitting developing countries according to the income level, respectively (upper-middle-income and lower-middle-income countries). Precisely, political globalisation is prominent in promoting FDI inflow with support of comprehensive financial development for upper and lower middle-income countries. We confirm that the presence of financial development helps FDI inflow. Financial development was established to lower the cost of investments by allowing foreign capital to access domestic financial markets and increase obtainable foreign capital (Mishkin, 2009). Our evidence also coincides with past studies, for instance, Levine (2005), Alfaro et al. (2009), Rad et al. (2016), and Hammudeh et al. (2020). However, we found the interaction of financial development and social globalisation diminish FDI inflow in upper and lower-middle-income countries while insignificant for overall developing countries. We strongly believe the negative relationship is due to social policy and financial policy impediments across countries. In addition, the insufficient power to adopt rapid globalisation and incomprehensive financial system and internal 
control due to poor governance may be the factor. Together, those factors contribute to negative relationships among developing countries: upper and lower-middle-income countries.

\section{CONCLUSION}

This study examines the political globalisation and social globalisation towards FDI inflow on developing and further splitting developing countries into upper and lower middle-income countries. Using the Eclectic theory and imperfection market hypothesis, we incorporate a sufficient sample of 42 countries during the period 1984-2016 and apply the CS-ARDL by controlling the $\mathrm{CD}$ in the long run and short run. The empirical findings provide several important policy implications. Political globalisation and social globalisation are eminent to FDI inflow in a conditional way. Overall, our finding confirms political globalisation presents a U-shaped relationship while social globalisation depicts a reverse U-shape. We argue that the readiness to absorb globalisation in the social structure is the factor that enforces social globalisation and fails to promote FDI inflow over developing countries. We further split developing countries into two subgroups which are upper and lower-middle-income countries, for robustness. We manifested political globalisation indicates a U-shaped relationship in upper and lower-middle-income countries. In contrast, social globalisation exhibits a reversed U-shaped relationship for upper-middle-income countries and a U-shaped relationship for lower-middle-income countries. Meanwhile, the monotonic linear relation between financial development and political and social globalisation for the upper and lower-middle-income countries implies that financial development is a stimulus element that allows high FDI inflows trend. Hence, the government should embrace and strengthen financial development by prompting credit and stock markets in the upper and lower-middle-income countries to embrace FDI inflows. We declared that incorporating decomposed globalisation component, political and social globalisation, and financial development are prominent in tackling foreign policy control development among upper and middle-income countries. Particularly, sufficient capacity to absorb globalisation, either political and social, could be policy implications for upper and lower middle-income countries and developing countries as a whole. All in all, we summarise that adopting political and social globalisation, and financial development are 
highly prominent in boosting FDI inflow. CS-ARDL confirmed that quality of governance based on our modelling investigation throughout developing country samples indeed provides positive and high significant relationships and caters to the $\mathrm{CD}$ problem in the short and long-run relationship. This study encourages the government of developing countries to strive for good governance in promoting FDI inflow. The high capacity of globalisation absorber will establish advanced technology and knowledge spillover that will be a gateway to FDI inflow. We noted that political globalisation works parallel with financial development. Strong financial development and the amalgamation of political and social globalisation embrace FDI inflow in upper and middle-income countries. While social globalisation presents unexpected results, we suggest countries increase preparation and readiness in absorbing globalisation nexus. Comprehensive financial development assists the financial institution in managing lumpy market opportunities. Hence, we encourage the government to promote capacity absorbing globalisation and financial integration in foreign exchange policy control acts across countries.

\section{ACKNOWLEDGEMENTS}

The authors would like express their gratitude to the Ministry of Higher Education for HICoE research funding, Accounting Research Institute, Universiti Teknologi MARA, Malaysia for all supports and resources.

\section{REFERENCES}

Acemoglu, D., \& Robinson, J. A. (2000). Why did the West extend the franchise? Democracy, inequality, and growth in historical perspective. The Quarterly Journal of Economics, 115(4), 1167-1199.

Aditya, S. (2006). Transport, geography, tribalism. London: Aditya Publications.

Alfaro, L, Ozcan S. K., \& Sayek, S. (2009). FDI Productivity and Financial Development. The World Economy, 32(1), 111-135. 
Ang, J. B. (2008). A survey of recent developments in the literature of finance and growth. Journal of Economic Surveys, 22(3), 536-576.

Arestis, P., Nissanke, M., \& Stein, H. (2005). Finance and development: Institutional and policy alternatives to financial liberalization theory. Eastern Economic Journal, 31(2), 245-263.

Arfat, S. (2013). Globalisation and human rights: An overview of its impact. American Journal of Humanities and Social Sciences, 1(1), 18-24.

Aryeetey, E., \& Ackah, C. (2011). The global financial crisis and African economies: Impact and transmission channels. African Development Review, 23(4), 407-420.

Bai, J., \& Ng, S. (2004). A PANIC attack on unit roots and cointegration. Econometrica, 72(4), 1127-1177.

Basak, G. K., \& Das, S. (2018). Understanding cross-sectional dependence in panel data. Arxiv Preprint Arxiv:1804.08326.

Batten, J. A., \& Vo, X. V. (2009). An analysis of the relationship between foreign direct investment and economic growth. Applied Economics, 41(13), 1621-1641.

Beck, T., Levine, R., \& Loayza, N., (1999). Finance and the sources of growth (World Bank Policy Research Working Paper, 2057). World Bank, Washington, D.C.

Carkovic, M. \& Levine, R. (2005). Does foreign direct investment accelerate economic growth? In T. H. Moran, E. M. Graham, \& M. Blomstrom (Eds.), Does foreign direct investment promote development? (pp. 195-220). Washington, DC: Institute for International Economics and Center for Global Development.

Chen, S., Saleem, N., \& Bari, M. W. (2019). Financial development and its moderating role in environmental Kuznets curve: Evidence from Pakistan. Environmental Science and Pollution Research, 26(19), 19305-19319. 
Chudik, A., Mohaddes, K., Pesaran, M. H., \& Raissi, M. (2016). Long-run effects in large heterogeneous panel data models with cross-sectionally correlated errors. In G. Gonzalez Rivera, R. Carter Hill, \& T. H. Lee (Eds.), Essays in Honor Of Aman Ullah, Advances in Econometrics, Vol. 36 (pp. 85-135). Bingley: Emerald.

Crouch, C. (2012). Democracy and capitalism in the wake of the financial crisis. In E. Amenta, K. Nash, \& A. Scott (Eds.), The Wiley-Blackwell companion to political sociology (pp. 478-490). Oxford: WileyBlackwell Publishing Ltd.

Darusalam, D., Omar, N., Said, J., Sohag, K., \& Janssen, M. (2019). The stimulus of globalization on quality of governance: Evidence from ASEAN countries. Paper presented at the RSU International Research Conference 2019. Retrieved from https://rsucon.rsu.ac.th/ files/proceedings/inter2019/IN19-222.pdf

Demirgüç-Kunt, A., \& Levine, R. (1996). Stock markets, corporate finance, and economic growth: An overview. The World Bank Economic Review, 10(2), 223-239.

Dreher, A. (2006). Does globalization affect growth? Evidence from a new index of globalization. Applied Economics, 38(10), 1091-1110.

Federici, D., \& Caprioli, F. (2009). Financial development and growth: An empirical analysis. Economic Modelling, 26(2), 285-294.

Hammudeh S., Sohag, K., Husain S., \& Said J. (2020). Nonlinear relationship between economic growth and nuances of globalization with income stratification: Roles of financial development and governance. Economic System, 44(3), 100761.

Hermes, N., \& Lensink, R. (2003). Foreign direct investment, financial development and economic growth. The Journal of Development Studies, 40(1), 142-163.

Howell, L. D. (2001). Political risk assessment: Concept, method and management. East Syracuse, NY: PRS Group. 
Im, K. S., Pesaran, M. H., \& Shin, Y. (2003). Testing for unit roots in heterogeneous panels. Journal of Econometrics, 115(1), 53-74.

Katircioglu, S. T., \& Taspinar N. (2017). Testing the moderating role of financial development in an environmental Kuznets curve: Empirical evidence from Turkey. Renewable and Sustainable Energy Reviews, $68,572-586$.

King, R. G., \& Levine, R. (1993a). Finance and growth: Schumpeter might be right. The Quarterly Journal of Economics, 108(3), 717-737.

King, R. G., \& Levine, R. (1993b). Finance, entrepreneurship and growth: Theory and evidence. Journal of Monetary Economics, 32(3), 513-542.

Kose, M. A., Prasad, E. S., \& Taylor, A. D. (2009). Thresholds in the process of international financial integration (NBER Working Paper 14916). Retrieved from http://www.nber.org/papers/w14916

Kose, M. A., Prasad, E., Rogoff, K., \& Wei, S. J. (2010). Financial globalization and economic policies. In Handbook of development economics (Vol. 5, pp. 4283-4359). Elsevier.

Levine, R. (2005). Finance and growth: Theory and evidence (NBER Working Paper 10766). Retrieved from http:/www.nber.org/papers/ w10766

Martell, L. (2007). The third wave in globalization theory. International Studies Review, 9(2), 173-196.

Mauro, P., (1995). Corruption and growth. The Quarterly Journal of Economics, 110(3), 681-712.

Milanovic, B. (2003). Two faces of globalization: Against globalization as we know it. World Development, 31(4), 667-683.

Mishkin, F. S. (2009). Globalization and financial development. Journal of Development Economics, 89(2), 164-169. 
Moon, H. R., \& Perron, B. (2004). Testing for a unit root in panels with dynamic factors. Journal of Econometrics, 122(1), 81-126.

North, D. (1990). Institutions, institutional change, and economic performance. Cambridge, New York: Cambridge University Press.

O'Connell, P. G. J. (1998). The overvaluation of purchasing power parity. Journal of International Economics, 44, 1-19.

Olson, M., Sarna, N., \& Swamy, A. V. (2000). Governance and growth: A simple hypothesis explaining cross-country differences in productivity growth. Public Choice, 102(3), 341-364.

Pesaran, M. H. \& Tosetti, E. (2011). Large panels with common factors and spatial correlation. Journal of Econometric, 161(2), 182-202.

Pesaran, M. H. (2004). General diagnostic tests for cross section dependence in panels (IZA Discussion Paper No. 1240). Retrieved from http://ftp. iza.org/dp1240.pdf

Pesaran, M. H. (2007). A simple panel unit root test in the presence of cross section dependence. Journal of Applied Econometrics, 22, 265-312.

Rad, S. S. E., Embong, Z., Mohd-Saleh, N., \& Jaffar, R. (2016). Financial information quality and investment efficiency: Evidence from Malaysia. Asian Academy of Management Journal of Accounting \& Finance, 12(1), 129-151.

Rajan, R., \& Zingales, L. (1998). Financial development and growth. American Economic Review, 88(3), 559-586.

Read, R. A. (2005). FDI and the creation of local linkages in small states. World Bank Knowledge Brief.

Rosenau, J. N. (2003). Distant proximities: Dynamics beyond globalization. Princeton: Princeton University Press.

Rosenberg, N., \& Birdzell, L. E., Jr. (1985). How the West grew rich: The 
economic transformation of the industrial world. New York: Basic Books.

Sadorsky, P. (2013). Do urbanization and industrialization affect energy intensity in developing countries?. Energy Economics, 37, 52-59.

Sarafidis, V., \& Wansbeek, T. (2010). Cross-sectional dependence in panel data analysis (Unpublished Working Paper, MPRA Paper No. 20367).

Stephan, F. F. (1934). Sampling errors and interpretations of social data ordered in time and space. Journal of the American Statistical Association, 29, 165-166.

Stiglitz, J. E. (2000). Capital market liberalization, economic growth, and instability. World Development, 28(6), 1075-1086.

Stiglitz, J., (2002). Globalization and its discontents. New York: W.W. Norton \& Company.

Stulz, R. M. (2005). The limits of financial globalization. The Journal of Finance, 60(4), 1595-1638.Termeer, C. J. A. M. (2009). Barriers to new modes of horizontal governance: A sense-making perspective. Public Management Review, 11(3), 299-316.

Wei, S. J. (2006). Connecting two views on financial globalization: Can we make further progress?. Journal of the Japanese and International Economies, 20(4), 459-481.

Wei, S. J., \& Wu, Y. (2002). Negative alchemy? Corruption, composition of capital flows, and currency crises. In Preventing currency crises in emerging markets (pp. 461-506). University of Chicago Press.

Wood, A., \& Ridao-Cano, C. (1999). Skill, trade, and international inequality. Oxford Economic Papers, 51(1), 89-119.

World Development Indicators (WDI). Retrieved on $11^{\text {th }}$ of April 2018 from Https://Datahelpdesk.Worldbank.Org/Knowledgebase/Articles/906519 